\title{
Support group for families with children in a pediatric intensive care unit
}

\author{
Grupo de apoio para famílias de crianças em unidade de terapia intensiva pediátrica \\ Equipo de apoyo a las familias de niños en Unidad de Cuidados Intensivos Pediátricos
}

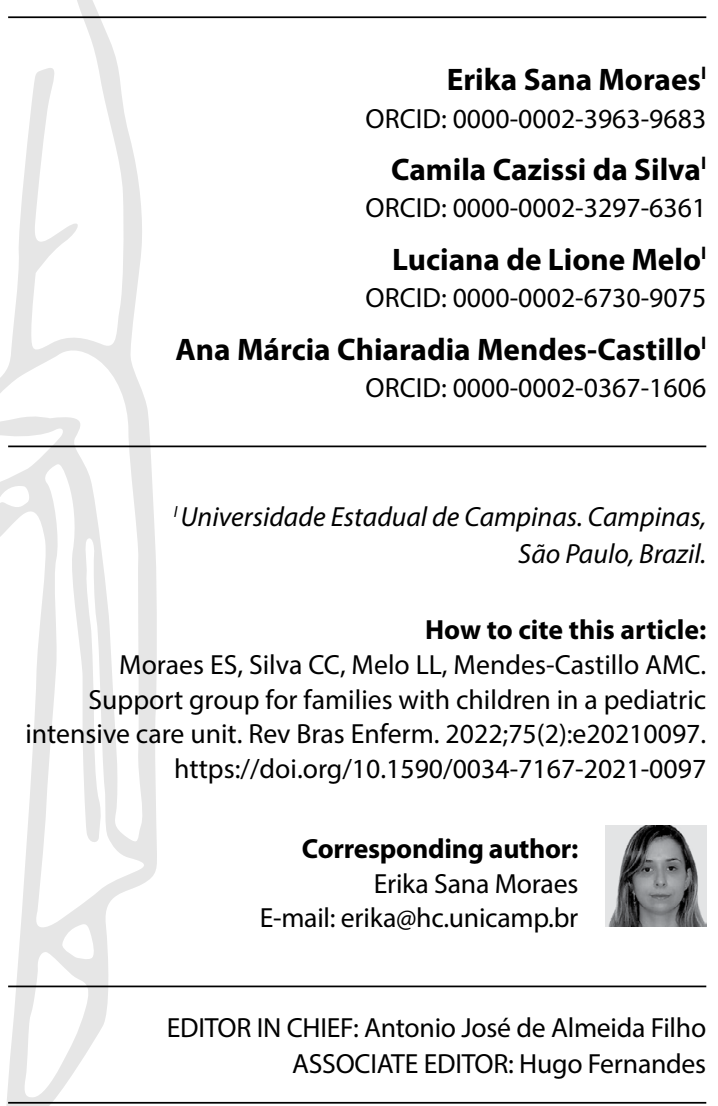

Submission: $02-23-2021$

Approval: 05-03-2021

\begin{abstract}
Objective: To describe the process of creating and implementing a support group for families with children in a pediatric intensive care unit. Methods: A professional experience report described using a management and planning tool. Results: This is a pioneering initiative in the hospital. The application of the tool enabled the delineation of the scope, justification, location, frequency, responsible persons, approach, and budget. After its implementation, the group enables significant interaction between health professionals-families and familiesfamilies, favoring the formation of therapeutic bonds and stimulating social and emotional support networks. Conclusion: The tool effectively planned the group and highlighted its effects on family coping and the relationships between professionals and families.

Descriptors: Self-help groups; Family; Intensive Care Units, Pediatric; Child, Hospitalized; Pediatric Nursing.
\end{abstract}

\section{RESUMO}

Objetivo: Descrever o processo de criação e implementação de grupo de apoio às famílias de crianças em unidade de terapia intensiva pediátrica. Métodos: Relato de experiência profissional descrito mediante uma ferramenta de gerenciamento e planejamento. Resultados: Trata-se de iniciativa pioneira no hospital. A utilização da ferramenta possibilitou o delineamento do escopo, justificativa, local, frequência, responsáveis, abordagem e orçamento. Após sua implantação, o grupo está possibilitando interação significativa profissionais de saúdefamílias e famílias-famílias, favorecendo a formação de vínculo terapêutico e estimulando redes de apoio social e emocional. Conclusão: A ferramenta foi eficaz no planejamento do grupo e destacou os efeitos deste no enfrentamento familiar e nos relacionamentos entre profissionais e famílias.

Descritores: Grupos de Apoio; Família; Unidades de Terapia Intensiva Pediátrica; Criança Hospitalizada; Enfermagem Pediátrica.

\section{RESUMEN}

Objetivo: Describir el proceso de creación e implementación de equipo de apoyo a las familias de niños en unidad de cuidado intensivo pediátrico. Métodos: Relato de experiencia profesional descripto mediante una herramienta de gestión y planeamiento. Resultados: Se trata de iniciativa pionera en el hospital. La utilización de la herramienta posibilitó el delineamento del objetivo, justificativa, local, frecuencia, responsables, abordaje y presupuesto. Después de su implantación, el equipo está posibilitando interacción significativa profesionales de salud-familias y familias-familias, favoreciendo la formación de vínculo terapéutico y estimulando redes de apoyo social y emocional. Conclusión: La herramienta fue eficaz en el planeamiento del equipo y destacó los efectos de este en el enfrentamiento familiar y en la relaciones entre profesionales y familias.

Descriptores: Grupos de Autoayuda; Familia; Unidades de Cuidado Intensivo Pediátrico; Niño Hospitalizado; Enfermería Pediátrica. 


\section{INTRODUCTION}

The pediatric intensive care unit (PICU) is a place surrounded by routines that restrict the family in the direct care for the child, which can be frightening and threatening to its members. In this context, the family seeks support to bear the emotional burden and avoid burnout. This support may come from family members, extended family, friends, other families in a similar situation, community, or spiritual leader, with the possibility of extending to members of the health care team ${ }^{(1)}$.

The social support network is the sum of all the relationships that an individual perceives as significant or differentiated from the anonymous mass of society. Many of these support networks are formed inside the hospital, emphasizing the family support offered by professionals and the network formed among the mothers of hospitalized children, who interact and join forces to support the family facing the child's illness ${ }^{(2)}$.

The use of support group technology in pediatrics has been adopted as a valuable way to stimulate interaction, provide support, enable interpersonal relationships, and favor the adaptation to the situation of having a hospitalized child in the family. In addition, it provides a space for the expression of feelings, needs, expectations, and anguish, stimulating the formation of social support networks ${ }^{(3)}$.

Understanding the aspects mentioned above and considering the context of the intensive care unit where the study was developed, it was identified the need to provide support, by the initiative of nurses of the unit, based on the results of two studies conducted there, in which it was evidenced the lack of support and difficulty of the relationship between staff and family ${ }^{(4-5)}$.

The first study carried out in the unit was conducted with grandparents of hospitalized children and found that the unmet demands are sources of pain and suffering, especially the lack of information about the grandchild's health ${ }^{(4)}$. The second study based on the experiences of nursing professionals regarding the presence of the family in the unit revealed that the inclusion of these members in care does not occur because the nursing team shows that it does not truly understand the importance of the family ${ }^{(5)}$. In this scenario, families did not have any type of support strategy, reception, or resources to stay full-time with the child.

Therefore, after identifying the need for modifications in the unit, it was necessary to use a quality management tool to enable the executive actions and outline action planning. To this end, it was chosen the $5 \mathrm{~W} 2 \mathrm{H}$, which can be used in several areas for problem analysis and resolution, project operationalization, action, and improvement plans ${ }^{(6)}$. As a facilitator for implementing improvement actions, it has been widely used by nursing, being fundamental for the definition of care and management standards.

\section{OBJECTIVE}

Describe the process of creating and implementing a support group for families with children in a pediatric intensive care unit.

\section{METHODS}

It will be shown a professional experience report on creating and implementing the support group in a PICU of a teaching hospital of a university in the countryside of the state of São Paulo (SP), which currently has 20 beds. In this unit, during the child's hospitalization, the family can stay during the daytime, and only one accompanying family member is allowed. There are also two daily visiting hours, from 11 am to $12 \mathrm{pm}$ and $4 \mathrm{pm}$ to $5 \mathrm{pm}$, allowing up to two people per day.

The creation of the group occurred after the analysis of the results of two studies conducted in the unit, which stimulated nurses to promote an intervention aiming to meet the care demands of families of children in PICU ${ }^{(4-5)}$. Initially, meetings were held with the multi-professional team of the unit, managers, and teachers to present the proposal and outline the steps for its implementation.

The group's implementation was described according to the management and planning tool called $5 \mathrm{~W} 2 \mathrm{H}$. Management tools like this come from management studies; it performs effective management and systematically and orderly recording of workflows and actions for the development of small or large projects. It is a qualified, structured, and practical plan of action, with well-defined steps, as follows: the step "what" defines the scope; "why" establishes the justification for the intervention; "where" defines the place where it will be carried out; "when" refers to the frequency of carrying out the intervention; "who" determines who is responsible for conducting the activities; "how" presents the strategies of approach, and the step "costs" (how much) predicts the necessary budget ${ }^{(6)}$.

That is a pioneering initiative in the mentioned hospital and started in November 2017, aimed at all family members present in the hospital environment and wished to participate in the activity. The action plan, known and approved by the unit's board of directors, comprised the following steps:

Chart 1 - Steps of the 5W2H tool for implementing the support group, Campinas, São Paulo, Brazil, $2021^{(6)}$

\begin{tabular}{|l|l|}
\hline WHAT: & $\begin{array}{l}\text { Create support group for families with children } \\
\text { hospitalized in PICU. }\end{array}$ \\
\hline WHY: & $\begin{array}{l}\text { The families with children hospitalized in PICU have a } \\
\text { great need for support and information, and the lack } \\
\text { of guidance and ineffective communication generate } \\
\text { anguish and suffering. }\end{array}$ \\
\hline WHERE: & $\begin{array}{l}\text { The place is a room intentionally located outside the PICU } \\
\text { to get away from the environment, alarms, and routine } \\
\text { for a short period to express feelings and anguish. }\end{array}$ \\
\hline WHEN: & Weekly one-hour meetings on Thursdays. \\
\hline WHO: & $\begin{array}{l}\text { The professionals involved are nurses and nursing } \\
\text { technicians, psychologists, physical therapists, } \\
\text { physicians, nutritionists, social workers, and chaplaincy. }\end{array}$ \\
\hline HOW: & $\begin{array}{l}\text { Group activities, information sharing, moments of } \\
\text { relaxation with beauty care, crafts, group dynamics, } \\
\text { and special activities on commemorative dates. }\end{array}$ \\
\hline HOW MUCH: & $\begin{array}{l}\text { The estimated cost is approximately fifty } 50 \text { reais per } \\
\text { month, through donations and used in resources for } \\
\text { the activities. }\end{array}$ \\
\hline
\end{tabular}

\section{RESULTS}

The $5 \mathrm{~W} 2 \mathrm{H}$ tool enabled the operationalization of the initial idea, delimiting and subsidizing all the necessary steps for its implementation, predicting the objective, responsible people, place, activities that would be performed as well as the necessary 
budget for the development and maintenance of the weekly activities, in order to observe flaws that could prevent the proper implementation of the project.

The group management and organization are carried out by two nurse leaders and contemplate the preparation of monthly schedules that offer the various activities to meet the families' demands, emphasizing the importance of multidisciplinarity, even though there are particular moments with each of the different professionals involved. The organizers are also responsible for booking and scheduling the place, publicizing activities weekly, managing the financial and material resources.

Since its implementation, 120 group meetings have already taken place. Each time, all family members are encouraged by health professionals to participate. Although fathers and grandparents have participated, the most significant are the mothers. As for the frequency of participation, for each meeting, there have been around $80 \%$ to $100 \%$ of family members present during the child's hospitalization, that is, from 16 to 20 family members per meeting.

The activities developed by the group involve several themes. There are meetings whose objectives are to share information. The participants' main doubts are clarified, usually about the institution's norms and routines and medical terms, devices, and treatment. In these meetings, all members of the multi-professional team participate.

Other meetings are held to strengthen religiosity and spirituality through ecumenical services led by the chaplaincy team. There are also structured meetings in the format of conversation rounds and group dynamics, used for welcoming, integration, and expression of feelings, being conducted by nurses, psychologists, and physical therapists.

Still, another important activity of the group consists of holding handicraft workshops led by members of the nursing team. In these workshops, patients develop several products. Part of these products is for the children themselves in the PICU, such as character masks and accessories (ties and neckties). Furthermore, items such as key chains, mobiles, jewelry, fabric flowers, and simple embroidery are made for other family members, as shown in Figure 1. Workshops of this nature have proven to be an excellent tool for distraction and express feelings and anguish. It is also worth mentioning the meetings directed by the physical therapists, in which the objective is focused on muscle relaxation and stretching.

We dedicate special attention to the activities on commemorative dates, such as Christmas, Mother's Day, Father's Day, Children's Day, and Easter, to offer comfort as a way to diminish the feelings of sadness commonly intensified on these occasions. For this, we usually associate moments of religiosity with small handicrafts, or we use small gifts of emotional value, such as cards made by the caregivers, photos of the children in costume, where the costume mask was made by the family, along with tributes paid by the entire multi-professional health team involved in the activities.

Among the broad spectrum of possible activities and are carried out in the group meetings, the ones that have occurred the most since its creation has been the craft workshops, followed by informative meetings and information sharing. It is worth mentioning that, although the initial idea of the meetings was to concentrate the activities for the informative meetings, some other activities have emerged by demand of the families involved: moments of beauty care, like doing nails; and moments of recreation, like movies and bingos made with donations from the families involved. This right of families to participate in the planning of activities is essential since they are the protagonists and recipients of these care actions.

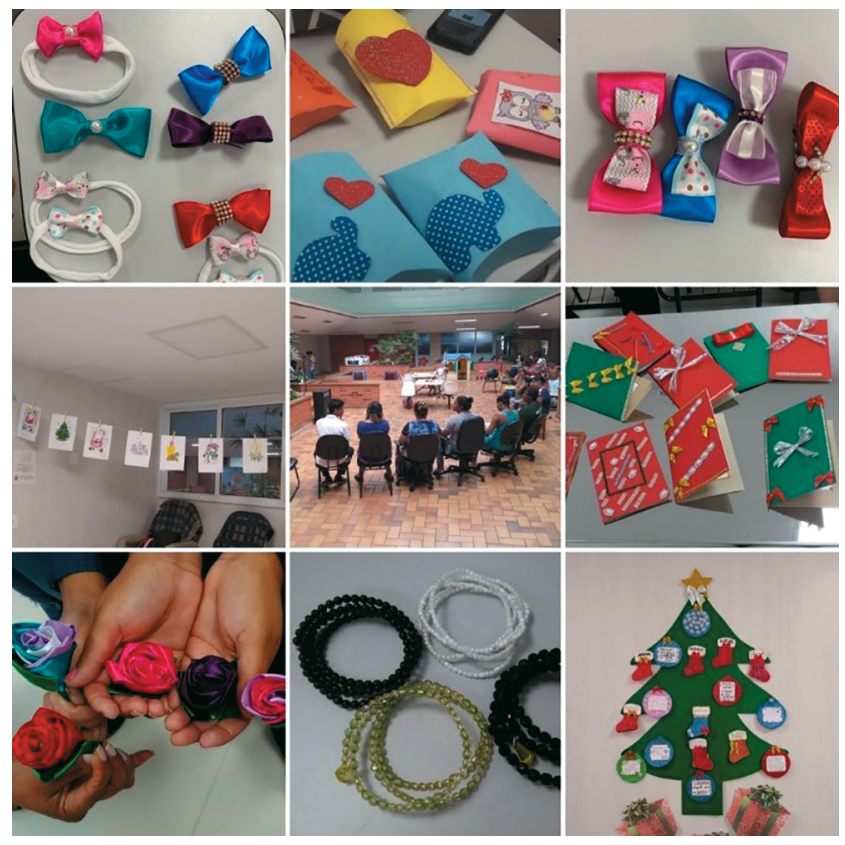

Figure 1 - Some of the products developed in the handcraft workshops, Campinas, São Paulo, Brazil, 2021

As a result of the meetings, we can highlight the opportunity to clarify doubts regarding hospitalization, the development of interaction and therapeutic bond between professionals and families and among the families; support; and the facilitation of forming a support network among families.

In this way, the group encouraged the health team to be sensitive and attentive to the families' needs, identifying and offering the necessary support and assistance. Due to the interactions, the relationship between families and the clinical team improved significantly, as observed by team members through fewer obstacles and barriers in the relationship with families and a reduction in complaints to the ombudsman.

Moreover, the group also enabled interaction among the families, providing moments of communication and sociability, facilitating the formation of mutual social support networks during hospitalization and that, not rarely, persists even after the child's discharge or transference.

In the first meetings after implementing the group, we found resistance from some families to participate, especially those newly admitted to the unit. However, this obstacle was managed by the group organizers through disclosure of the activities and the group's outcomes, aiming to encourage participation. Despite these efforts by the team, it is worth mentioning that, without a doubt, the most relevant factor in improving adhesion came with time, through the reports of families who had already participated in the meetings and who encouraged other families. 


\section{DISCUSSION}

Communication and information sharing are needs of families in the context of their child's hospitalization, and failures in this process can cause anxiety and fear. Parents expect and need regular and frequent feedback on their child's progress and condition and perceive it as part of their parental role to acquire information about their child's treatment ${ }^{(6)}$.

Studies developed with groups of parents of children in neonatal and pediatric intensive care units showed that this space was identified as an opportunity to clarify doubts about the family about the clinical conditions of the child and procedures performed for treatment. The information provided by professionals allows family members to feel safe to organize their emotional life, mobilizing internal resources to face the situation ${ }^{(3,7)}$.

In these moments of information sharing and clarification of doubts, the participating families observed the behavior and reactions of other families going through similar experiences and identified themselves with the problems of others. These studies have shown that the family attributes positive meaning to the participation in the group, identifying with the doubts of other participants, and reaching the necessary clarification ${ }^{(3,7-8)}$.

In this sense, families develop strategies to face their children's illness; thus, almost instinctively, they establish new relationships in the hospital and start to live with other families. They create bonds of friendship, become supportive, and, in this exercise of solidarity, sympathize with each other's suffering, and at the same time, they try to console each other ${ }^{(2)}$.

In this way, a shared social support network is built to go through this painful period of their children's hospitalization. This consolation and mutual support process have been evident in the support groups ${ }^{(4)}$.

Family members refer that, by sharing their experiences during the support group's activities, they end up getting more vital for being able to perceive the "other" who is next to them, potentiating the strengths of the collectivity ${ }^{(7)}$. The group becomes a space for exchanging experiences in which families identify with each other, learn from other families' experiences, and become calmer and more confident when they realize that others have already gone through the same problems and have overcome them ${ }^{(3)}$. Thus, mutual support is a strategy capable of providing the development of new expectations, reinforcing hope in difficult situations ${ }^{(2)}$.

The exchange of experiences, mutual support, and information sharing were also present in groups in situations beyond hospitalization. A recent study describes the importance of the support group for parents of transgender children, as family members gained and shared knowledge about the medical, legal, and political aspects of parenting a transgender child. In these moments, family members came into contact with the experiences of other parents, parents of older children, and this helped them understand choices intellectually, enabling discussions about complex issues ${ }^{(8)}$.

Emotional support significantly impacts support groups, being the most frequently mentioned by participants in several scenarios $^{(3,7-10)}$. In the support group for family members of transgender children, parents reported this support as the primary outcome of the group, for having the chance to listen to others and share their own experiences, which helped them reduce anxiety and feelings of fear, realizing that they are not alone. Participants described the other parents in the support group as friends, "chosen family," and as part of their support network, as well as reporting that they felt happy to share experiences, and these relationships were described as especially important ${ }^{(8)}$.

In this sense, emotional support is highlighted in support groups for mothers of children with disabilities, who experienced stress relief in exchanging experiences and suggesting possible solutions in an environment of care and trust, besides identifying the need for moments of fun to improve well-being ${ }^{(9)}$.

A study conducted with a support group for caregivers of dementia patients revealed the positive interaction between family members, which provided improved mood, well-being and also positively influenced self-esteem, allowing caregivers to better cope with caregiving. The process of discussing positive experiences in the group helped maintain caregivers' motivation and sense of meaning to continue providing care ${ }^{(10)}$.

The group is a space of care offered to the family beyond the already mentioned aspects of information, emotional support, and social support, also allowing the approximation of health professionals with the family, favoring the relationships of trust and helping family members to deal with the emotional stresses resulting from hospitalization. Thus, they feel valued by the team, which increases the bond between both parties ${ }^{(7)}$.

In our practice, the support group for families provided better communication between families and the team and, consequently, the development of interactions that favored the creation of bonds. Moreover, it provided opportunities and encouraged the team to be more attentive to the families' needs. This reality was also described in a study carried out with a neonatal unit's parents' group. The group was characterized as a facilitator scenario of interaction with professionals, allowing the family to get closer to them, making the interaction close, and building a relationship of trust ${ }^{(3)}$.

The group of this study was created with a multidisciplinary character, as in other studies, due to the importance of different views, to facilitate and improve the clarification of doubts - since it is possible to directly access the various health professionals - and the relevance of involving the whole team in the support and bonding network ${ }^{(3,7)}$. After its implementation, we noted greater interest from professionals who were not yet involved, raising their awareness to participate in the activities.

The implementation process showed the resistance of some families to participate, especially those newly admitted to the unit. As evidence of this, a study developed in a PICU reports a similar reality, which is due to different reasons, such as not wanting to leave the child alone, not being able to move away, not knowing how it works, or even not wanting or not being able to talk about the experience they were living ${ }^{(7)}$.

However, the weekly invitation to all families and the group's publicity in places where they usually stay have positively affected and improved the adhesion to the meetings. It is also worth mentioning the importance of the publicity and the invitation between family members, in which one member invites the other, presenting their support group and the benefits experienced, 
thus reinforcing the importance of the social support network developed in the hospital environment and stimulated by the actions of the group.

\section{Limitations of the Study}

We presented a report of professional experience based on the process of creation and implementation of a support group; therefore, studies are needed to understand the perspective of professionals and family members about their experience and the outcomes.

\section{Contributions to the field of Nursing}

We believe that this study can contribute to nursing in several areas by providing a perspective for implementing child- and family-centered care activities in the context of the pediatric intensive care unit. We also believe that this work can help nurses outline the steps to implement this intervention, from the scope, justification, location, frequency, responsibility, approach, and budget.

\section{CONCLUSION}

The objective of this study was to describe the process of creation and implementation of a support group for families of children in a pediatric intensive care unit; thus, by using the $5 \mathrm{~W} 2 \mathrm{H}$ planning tool, the project was outlined in stages, enabling its operationalization with a focus on scope, justification, responsible persons, budget, and necessary materials. It is a simple, fast, and effective strategy for organization and management applicable in various nursing fields.

Thus, after its creation and implementation, the support group provides families with more than an environment to exchange experiences: it provides information, emotional support, social support networks, and essential bonds during the painful experience of the child's hospitalization. These possibilities have been transforming the already existing relationships, creating new networks, and enabling new ways of coping with hospitalization.

There were families newly admitted to the unit that had initial resistance to participate in the group as a difficulty encountered. The solution found to this difficulty was to make weekly posters to promote the activities.

Regarding the professionals involved, significant interactions were built, facilitating and favoring the bond, besides sensitizing other team members to engage in the group's activities. As a result, the relationship between the families and the clinical team has improved significantly.

This report brought the implementation process of the support group, including the main difficulties of this phase. Currently, the group is solidified in the unit; and its bond with the team has been established. Thus, we believe that the next steps are to evaluate the results of these activities from the perspective of family members and professionals.

\section{ACKNOWLEDGEMENTS}

The author would like to thank the Pediatric Nursing Services of the Clinical Hospital of the University of Campinas - UNICAMP.

\section{REFERENCES}

1. Hagstrom S. Family stress in pediatric critical care. J Pediatr Nurs. 2017;32:32-40. https://doi.org/10.1016/j.pedn.2016.10.007

2. Molina RCM, Higarashi IH, Marcon SS. Importância atribuída à rede de suporte social por mães com filhos em unidade intensiva. Esc Anna Nery. 2014;18(1):60-7. https://doi.org/10.5935/1414-8145.20140009

3. Balbino FS, Yamanaka Cl, Balieiro MMFG, Mandetta MA. Grupo de apoio aos pais como uma experiência transformadora para a família em unidade neonatal. Esc Anna Nery. 2015;19(2):297-302. https://doi.org/10.5935/1414-8145.20150040

4. Moraes ES, Mendes-Castillo AMC. A experiência dos avós de crianças hospitalizadas em Unidade de Terapia Intensiva Pediátrica. Rev Esc Enferm USP. 2018;52:e03395. https://doi.org/10.1590/s1980-220x2017040003395

5. Silva CC, Souza MA, Cabeça LPF, Melo LL. Ways of being of nursing professionals in the pediatric intensive therapy: experiences with families. Rev Mineira de Enferm. 2020;24:e-1305. https://doi.org/10.5935/1415-2762.20200042

6. Seleme R, Stadler. Controle da qualidade: as ferramentas essenciais. Curitiba: IBPEX; 2008.

7. Hiiling MG, Ribeiro NRR. Grupo de pais da unidade de terapia intensiva pediátrica: percepção dos familiares. Cienc Cuid Saude. 2012;11(1):58-65. https://doi.org/10.4025/cienccuidsaude.v11i1.18859

8. Hillier A, Torg E. Parent participation in a support group for families with transgender and gender-nonconforming children: "Being in the company of others who do not question the reality of our experience". Transgend Health. 2019;4(1):168-75. https://doi.org/10.1089/ $\operatorname{trgh} .2018 .0018$

9. Mitwalli S, Rabaia Y, Kienzler H. Support groups for mothers of children with a handicap: a quantitative and qualitative study. Lancet. 2018;391(Suppl 2):S47. https://doi.org/10.1016/S0140-6736(18)30413-6

10. Lauritzen J, Bjerrum MB, Pedersen PU, Sørensen EE. Support groups for carers of a person with dementia who lives at home: a focused ethnographic study. J Adv Nurs. 2019;75:2934-42. https://doi.org/10.1111/jan.14151 